\title{
Isolation and Characterization of Palm Wine Strains of Saccharomyces cerevisiae Potentially Useful as Bakery Yeasts
}

\section{Olabisi Oloruntoba Olowonibi}

Department of Microbiology, Kogi State University, Anyigba, Nigeria

Corresponding author: Olabisi Oloruntoba Olowonibi, Department of Microbiology, Kogi State University, Anyigba, Nigeria, Tel: +2348050204542; E-mail: bisi4greatness08@gmail.com

Received Date: November 05, 2016; Accepted Date: March 27, 2017; Published Date: April 07, 2017

Copyright: (c) 2017 Olowonibi 0O. This is an open-access article distributed under the terms of the Creative Commons Attribution License, which permits unrestricted use, distribution, and reproduction in any medium, provided the original author and source are credited.

Citation: Olowonibi OO. Isolation and Characterization of Palm Wine Strains of Saccharomyces cerevisiae Potentially Useful as Bakery Yeasts Eur Exp Biol 2017, 7:11

\section{Abstract}

A total of 12 yeast isolates from palm wine collected from various locations in Anyigba and its environs were selected for their leavening activities and were identified. The yeasts demonstrated high levels of leavening activities between 82-94. $7 \%$ as compared with commercial yeast (100\%). Those that showed good leavening activities and were positive in assimilation tests for glucose, sucrose, maltose, galactose, lactose, raffinose and negative for lactose, xylose, lysine, nitrate and urea, were identified as Saccharomyces cerevisiae, while those that were positive in assimilating nitrate and lysine were identified as Candida spp. The yeasts were further assessed for attributes relevant to bakery operations such as production of $\mathrm{CO}_{2}$, temperature tolerance, ethanol tolerance, osmotic tolerance and flocculence. The rate of production of $\mathrm{CO}_{2}$ from different sugars ranges from 0.043 to $0.078 \mathrm{ml} / \mathrm{min}$. The levels of $\mathrm{CO}_{2}$ produced by the palm yeasts in the presence of maltose were appreciably lower than that of the commercial yeast. The yeasts were able to grow at temperatures $30,37^{\circ} \mathrm{C}$ and a few grew at $45^{\circ} \mathrm{C}$ though very sparely. Also, the yeast were tolerant to 8 and $10 \%$ ethanol but had very low tolerance to $13 \%$ ethanol. There was an appreciable tolerance to 6 and $8 \% \mathrm{NaCl}$ but a few numbers sparingly at $10 \% \mathrm{NaCl}$. Some of the isolates demonstrated flocculation ability. In general, the studies indicate that Saccharomyces cerevisiae strains from palm wine samples from Kogi State have good properties for industrial usefulness in bakery operations.

Keywords: Saccharomyces cerevisiae; Characterisation; Palm wine; Carbon dioxide; Fermentation; Leavening

\section{Introduction}

Microbes are generally regarded as part of wildlife or undeveloped raw materials of a locality, region or nation. Therefore, the practice of isolating and evaluating local microbial strains for defined or potential commercial attributes is a common practice in industrial microbiology/microbial biotechnology. For isolating organisms of interest, diverse environments-soil, water, foods, are usually screened by using appropriate techniques. Geographical and climatic factors influence abundance and physiology of microbes. Scientists often transverse international boundaries during environmental screening. For example, some British experts collected a sample of soil from Northern Nigeria and screened it with some success, for antibiotic producing microorganisms [1]. In general, various microbial isolates that have been appropriately preserved and routinely cultivated for commercial production of biomass, enzymes, antibiotics, organic acids, to mention but a few, have resulted from such screens [2].

Saccharomyces cerevisiae is yeast (a unicellular fungus). It is commonly isolated from sugary foods and alcoholic beverages including local ones such as palm wine and Burututu beer [3]. The organism has fermentative and oxidative capabilities; thus, it can ferment sugars and produce alcohol (mainly ethanol) and carbon dioxide under anaerobic conditions, and it can grow rapidly on sugar and produce high yields of biomass under aerobic conditions. Worldwide, the two attributes are exploited industrially, and suitable strains of yeast are used in production of beers, wines, breads, fuel alcohol, nutritional yeast biomass and by-products from these. Yeasts usually used for baking are carefully selected strains of Saccharomyces cerevisiae. By enzymatic action, it converts fermentable sugars and some of the starch present in the dough into carbon-dioxide and alcohol and the $\mathrm{CO}_{2}$ causes the dough to rise [4].

The discovery of the use of yeast to leaven bread centuries ago lead to the growth of bakery industry. However, bakers used brewer's yeast till about 80-1000 years ago due to its performance in the bakery which was low and variable. It was the isolation of a special strain-Saccharomyces cerevisiae possessing the desired characteristics that brought about revolutionary changes in the bakery industry. Fermented beverages are well known to harbor heterogeneous microfloras that invariably include yeasts. In Nigeria, especially the Southern part, palm wine, the fermented sap of oil palm tree (Elaeis guineensis) is a popular beverage. The microbiology has been well studied and review of literature is available [5]. Saccharomyces cerevisiae is a component of palm wine and many Nigerian workers have explored both biological and economic aspect of the species found in palm wine. For 
example, Ayanru [6] observed morphological and physiological variants or races that could affect organoleptic qualities of palm wine. Other workers have described strains potentially useful as leavening agents or for production of wine, beer, and fuel ethanol, as appropriate [7-9].

An overwhelming wealth of information on genetics, molecular biology and physiology has accumulated on this organism making this traditional species the best-characterized eukaryotic system today. Several limitations, in terms of using $S$. cerevisiae as a tool for heterologous production, have been reported in the past. These included reduced biomass yield due to aerobic alcohol fermentation, very low yields (with a maximum of $1-5 \%$ of total protein), hyper glycosylation, plasmid instability, and the retention of protein in the periplasmic space. It is due to these limitations that attention was redirected to non-Saccharomyces or non-conventional yeasts as hosts for heterologous production of proteins [10].

Since the yeast cell is a living organism, it has numerous nutritional needs and it is only if these are met that it will grow vigorously and produce a large quantity of carbon dioxide. Food and moisture are needed for this growth [11].

Saccharomyces cerevisiae differs from other yeast species. It has more aerobic growth habit, maximum yielding capability stability during storage. It is usually derived from special selection of fast growing (short generation time) naturally occurring yeast strains [12].

Palm wine is a milky alcoholic beverage produced from the inflorescence of palm tree. It is the most widely used and cherished natural traditional alcoholic beverage especially in the southern part of Nigeria, and is the juice of the oil palm (Elaeis guineensis), and raffia palm (Raphia hookeri) [13].

A milky juice containing initially well over $13 \%$ sucrose when it is collected in the calabash which is hung at the base of the incision of the inflorescence of palm tree soon after leaving the tree, yeast spores, especially those of Saccharomyces cerevisiae infect the juice and soon start to ferment the fermentable sugar. Palm wine can be consumed as an alcoholic beverage. It could be allowed to ferment and subsequently distilled into gin. It could also be used for the leavening of dough for bread making [14].

The use of palm wine as a leavening agent for dough is attributed to the presence of a yeast strain contained in the palm sap. This yeast strain is Saccharomyces cerevisiae or baking yeast as it is called in the bakery industry [15].

The characteristics of palm wine are so unique that it has generated research interest [16] to investigate the practical applications and industrial applications. The determination the physiological characteristics of palm wine yeast isolates and some isolates showed tolerance to high sucrose and ethanol concentrations: the properties that can be exploited. Similarly, the efficiency of yeast isolates from palm wine in diverse fruit wine production and concluded that acceptable wine could be produced from fruits with palm wine yeasts [17].

\section{Statement of problem of the study}

The type or nature of yeasts with leavening activity from palm wine samples from Kogi State (Nigerian middle belt) may have peculiar characteristics. Information on physiological studies of such indigenous yeasts from Anyigba and environs is not available; this information is required for domesticating such yeasts for bakery operation.

Further studies on the yeasts may give some good qualities and properties which will improve products in the bakery industry.

\section{Justification for the study}

Isolation and development of suitable microbes for use in production processes of economic importance are crucial in biotechnology. Indigenous strains must be isolated and subjected to rigorous studies before they can be reliably used for this purposes, as starter cultures.

The findings of this study would provide a basis for comparing palm wine yeasts from Nigeria middle belt with those described in earlier reports and would also help to confer middle belt palm wine yeasts with different industrial useful properties.

\section{Methods}

\section{Sources and collection of samples}

Fresh wine samples obtained from oil palm (Elaensis guineensis) were collected from palm wine tapers within 30-60 minutes of tapping in sterile $25 \mathrm{ml}$ screw-capped bottles and were brought to the laboratory of Microbiology Department, Kogi State University, Anyigba, for analysis within two hours of collection. Sampling was done on three different occasions, from local markets of Anyigba, Abocho, Ajiolo, Egume, Okura and Ochadamu in Kogi State of Nigeria.

\section{Isolation and preliminary identification of yeasts}

Each palm wine sample was shaken vigorously by hand within 1-2 hrs of collection and plated on triplicate potato dextrose agar (PDA) plates containing $0.05 \mathrm{mg} / \mathrm{ml}$ of chloramphenicol and gentamicin to inhibit bacterial growth.

Table 1: Sources and codes for palm wine samples.

\begin{tabular}{|l|l|l|}
\hline Sample code & Sample & Source \\
\hline AY & Palm wine & Anyigba \\
\hline AB & Palm wine & Abocho \\
\hline AJ & Palm wine & Ajiolo \\
\hline EG & Palm wine & Egume \\
\hline OK & Palm wine & Okura \\
\hline OC & Palm wine & Ochadamu \\
\hline
\end{tabular}

Plates were incubated at room temperature $\left(25 \pm 2^{\circ} \mathrm{C}\right)$ for a maximum of $48 \mathrm{hrs}$. Representative colonies (confirmed to be 
yeasts by microscopy) were purified by restreaking on PDA plates and isolates were stored on slopes of the same medium. Isolates were sub cultured as needed for the various experiments conducted in this work. Yeast isolates were identified by standard morphological and physiological methods and identification methods as described by Barnett et al. [18] and Phaff and Starmer [19] were used (Table 1).

\section{Microscopy examination}

Macroscopically, isolates were observed for the following feature: colony elevation, colour and other distinct and unique features. For microscopy, thin smear was prepared in accordance to Fawole and Oso [20], by emulsifying a loopful of an isolate under test on a clean slide with a drop of water. The film was spread to make a thin film and then air dried after which it was stained with a methylene blue dye and observed with a light microscope under X10 and X40 objective lenses.

\section{Glucose fermentation test}

The isolates were tested for their ability to assimilate and to ferment glucose. For the fermentative test, isolate was inoculated into a test tube containing an inverted Durham tube and peptone water containing 1-3 of the sugar (glucose) and a drop of Andrade's indicator. It was incubated for 24-48 hours, change in color (pink to yellow) or otherwise, of the indicator as well as liberation and trapping of gas trapped in the Durham's tube indicate the result of each test; the presence of gas was taken as an evidence of a reasonably high rate of fermentative activity [21].

\section{Biochemical tests for the identification of yeasts}

Carbon assimilation test: Yeast Nitrogen Base (Difco) (YNB) broth (the base contains all essential nutrients and vitamins necessary for the cultivation of yeasts except a source of carbon) was prepared by adding $6.7 \mathrm{~g}$ of base and $5 \mathrm{~g}$ of carbohydrate to $100 \mathrm{ml}$ of distilled water (warmed). The preparation was thoroughly mixed, filter sterilized and stored in refrigerator at $2-8^{\circ} \mathrm{C}$ for a maximum of one week before use. An inoculum culture of the test organism was grown on PDA plates for two days at $25^{\circ} \mathrm{C}$ and used to inoculate the YNB carbohydrate broth medium which was incubated at $25^{\circ} \mathrm{C}$ for 6-7 days. After incubation, the tubes were shaken and released to determine whether growth had occurred. The carbohydrates tested using YNB were glucose, sucrose, maltose, xylose, galactose, lactose, raffinose, melibiose, mannitol, and trehalose [22].

Nitrogen assimilation: Yeast Carbon Base (Difco) broth was used. The base contains all essential nutrients and vitamins necessary for the cultivation of yeasts except a source of nitrogen. For the preparation of the broth, $11.7 \mathrm{~g}$ of the base and a $2 \mathrm{~g}$ of nitrogen source in $100 \mathrm{ml}$ of distilled water, was thoroughly mixed, filter sterilized and stored at $2-8^{\circ} \mathrm{C}$. The prepared medium was dispensed in tubes aseptically and inoculated with the test organism as described above for YNB assimilative test. After incubation, the tubes were shaken to access growth. The nitrogen sources for the experiment were lysine and nitrate [23].
Urea hydrolysis: Urea broth was prepared by mixing $9.68 \mathrm{~g}$ of Urea R broth (Difco) and distilled water of $250 \mathrm{ml}$, which was filter-sterilized. From which $0.5 \mathrm{ml}$ volume was dispensed aseptically into sterile empty test tubes.

Each experimental organism was inoculated into its appropriately labeled tube by means of a flame-sterilized inoculation loop and was incubated for $24-48$ hours at $37^{\circ} \mathrm{C}$. The incubated broths were observed for color change from yellow to bright pink [24].

\section{Leavening activity of the yeast isolates}

Propagation of yeasts for determination of leavening activities: Yeasts selected on the basis of their fermentative ability were propagated in the following way:

A loopful of each strain was suspended in 1-2 $\mathrm{ml}$ sterile distilled water in a test tube and $0.1 \mathrm{ml}$ volume of the suspension was spread on two PDA plates which were incubated at room temperature for $24 \mathrm{hrs}$.

The lawns of cells were scraped off and suspended in tap water to give a standard turbidity; a 10-fold dilution of the suspension had an absorbance of 0.14 at $550 \mathrm{~nm}$. A commercial brand of baker's yeast preserved on a slope, was propagated on agar plates and used to prepare a suspension using the same method [25]

Assessment of yeasts leavening activities: The leavening activity of the yeasts was tested by modification of the cylinder method. For each strain a smooth dough mixture containing wheat flour-20 g; sugar cane- $2 \mathrm{~g}$; and yeast suspension- $15 \mathrm{ml}$ was prepared. The mixture was poured slowly into a clean 100 $\mathrm{ml}$ measuring cylinder which had been smeared on the inside with a thin layer of groundnut oil to aid deposition of the dough at the bottom of the cylinder. After reading the initial volume of the dough in the cylinder, it was incubated at $37^{\circ} \mathrm{C}$ and subsequent volumes recorded at regular intervals [26].

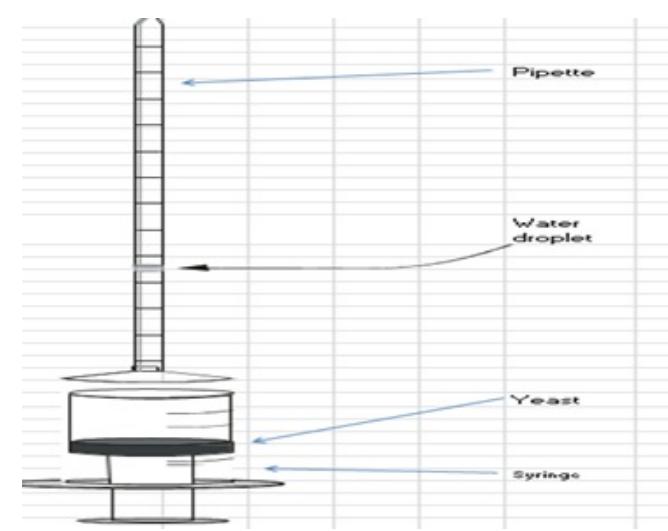

Figure 1 Respirometer apparatus for the determination of the rate of $\mathrm{CO}_{2}$ Production.

\section{Rate of $\mathrm{CO}_{2}$ production}

The experiment performed was carried out using the respirometer apparatus shown in Figure 1. 
The yeast suspension (prepared as in the leavening activity above) was placed into a syringe and the $\mathrm{CO}_{2}$ released by the cells pushed a small water droplet up a pipette, which allowed the volume of $\mathrm{CO}_{2}$ which was measured at different times over a period of 15-20 minutes.

The rate of cellular respiration by yeast cells was conducted by adding $10 \mathrm{ml}$ of distilled water and $1.0 \mathrm{~g}$ of glucose to a $50 \mathrm{ml}$ flask. Then $10 \mathrm{ml}$ of the yeast suspension was transferred to the flask. The yeast suspension was incubated for 5 minutes, with occasional swirling. $3 \mathrm{ml}$ of the yeast suspension was taken with a syringe. The syringe was inverted and $1 \mathrm{ml}$ of air was drawn above the liquid.

A $2 \mathrm{ml}$ pipette was attached to take measurement as soon as the water droplet reached the $0 \mathrm{ml}$ mark and at 3 minutes intervals. The above experiment was also repeated for fructose, sucrose, maltose and mixed sugars, but for the mixed sugars composition $(0.5 \%$ Glucose, $0.5 \%$ fructose, $3 \%$ sucrose and $1 \%$ maltose) to mimic sugar utilization in dough raising $[27,28]$. The data were recorded.

\section{Stress exclusive tests}

Temperature tolerance test: The ability of the yeast to grow at higher temperatures was verified by plating the yeast isolates onto Potato Dextrose Agar medium and incubated at 3 different temperatures i.e. 30,37 and $45^{\circ} \mathrm{C}$ for 72 hours [29]. The resulting growth was observed and recorded in the results.

Determination of ethanol tolerance: The ability of the isolated yeast strains to grow in higher ethanol concentrations medium were tested in relation to varying sample locations by growing them in potato dextrose broth containing 3 different concentrations of ethanol, $10 \%, 13 \%$ and $15 \%(\mathrm{v} / \mathrm{v})$, respectively and incubated at $30^{\circ} \mathrm{C}$ for 72 hours [30].

Osmotolerance: Yeast cells were harvested at the required phase of growth and washed twice in phosphate buffer, $\mathrm{pH} 5.9$ (89. $85 \mathrm{ml} ; 0.1 \mathrm{M} \mathrm{NaHPO}_{4}: 10.15 \mathrm{ml} ; 0.1 \mathrm{M} \mathrm{Na}_{2} \mathrm{HPO}_{4}$ diluted to $200 \mathrm{ml}$ ). Two day old cells were resuspended in $100 \mathrm{ml}$ of $\mathrm{NaCl}$ $(4,6,8$, and $10 \% \mathrm{w} / \mathrm{v})$. The tubes were incubated at $25^{\circ} \mathrm{C}$ and readings taken after $40 \mathrm{hrs}$ [31].

Flocculation test: In this test, isolates were inoculated in 10 $\mathrm{ml}$ of Potato Dextrose broth and incubated at $30^{\circ} \mathrm{C}$ for three days. After incubation, tubes were agitated to observe the flocculation formed. After incubation the culture supernatant was carefully decanted and the adhesion of the yeast sediment to the bottle was observed and recorded. The sediment was then suspended and the degree of flocculation assessed visually [32].

\section{Results}

\section{Morphological observations}

After three days of incubation at $25^{\circ} \mathrm{C}$ on potato dextrose agar incorporated with tetracycline and gentamicin, colonies suspected to be yeasts had unique earthy smells. Other characteristics were color ranging from cream white to colorless, Shape and form of oval, round shapes and occurring singly. All the isolates had raised elevation. The colonies of yeast strains possessed morphological features which corresponded to $S$. cerevisiae species

In broth culture, the isolates had flocculent deposits. Microscopic observation of the isolates showed the cells to be ovoid to circular shape cells, the size ranged from 2 to $6 \mu \mathrm{m}$. No filament was observed in any of the isolates when samples were taken from colonies growing on a potato dextrose agar. All the isolates had budding cells. Spores were not observed under the cultural condition used in this study

The colonies of yeast strains possessed morphological features which corresponded to $S$. cerevisiae specie.

\section{Biochemical identification test result of the isolates}

The result of sugar utilization test carried out showed that the isolates were capable of utilizing a wide range of sugars as carbon and energy sources. The utilization of sugars of carbohydrate fermentation was shown by the change in the color of the Andrade's indicator used in this test to pink, and by production of gas which was trapped in the inverted Durham's tubes.

A preliminary test was done for each of the isolates for fermentative and assimilation of glucose. Each isolate was then tested for assimilation of several sugars (the sugars were sucrose, maltose, xylose, galactose, lactose and raffinose) in other to identify the isolate to the genus Saccharomyces and also to the species level S. cerevisiae.

The ability of yeast to assimilate Glucose, Raffinose and Maltose confirmed for $S$. cerevisiae while some isolates that could assimilate lysine and nitrate confirmed Candida spp. Some of the isolates that could not ferment glucose, no further test were performed on them (Table 2).

Table 2 Biochemical identification test result of the isolates.

\begin{tabular}{|c|c|c|c|c|c|c|c|c|c|c|c|c|c|c|}
\hline \multirow{3}{*}{ Isolates } & \multicolumn{14}{|c|}{ Assimilation or Reactions } \\
\hline & \multicolumn{11}{|c|}{ Carbon compounds } & \multicolumn{3}{|c|}{ Nitrogen compounds } \\
\hline & Glu & Suc & Mal & Xyl & Gal & Lac & Raf & Mel & Man & Tel & Ery & Lys & Urh & $\mathrm{NO}_{3}$ \\
\hline AY1 & + & + & + & - & + & - & + & - & - & + & - & - & - & - \\
\hline AY3 & + & + & + & - & + & - & + & - & - & + & - & - & - & - \\
\hline
\end{tabular}




\begin{tabular}{|c|c|c|c|c|c|c|c|c|c|c|c|c|c|c|}
\hline AY7 & + & + & + & - & + & - & + & - & - & + & - & - & - & - \\
\hline AB2 & + & + & + & - & + & - & + & - & - & + & - & - & - & - \\
\hline AB3 & + & + & + & - & + & - & + & - & - & + & - & - & - & - \\
\hline $\mathrm{AB} 7$ & + & + & + & - & + & - & + & - & - & + & - & - & - & - \\
\hline AJ2 & + & + & + & - & + & - & + & - & - & + & - & - & - & - \\
\hline AJ4 & + & + & + & - & + & - & + & - & - & + & - & - & - & - \\
\hline EG2 & + & + & + & - & + & - & + & - & - & + & - & - & - & - \\
\hline EG5 & + & + & + & - & + & - & + & - & - & + & - & - & - & - \\
\hline OK4 & + & + & + & - & + & - & + & - & - & + & - & - & - & - \\
\hline OC5 & + & + & + & - & + & - & + & - & - & + & - & - & - & - \\
\hline
\end{tabular}

\section{Leavening activity results}

Appendix A shows the leavening activity of the yeasts that showed fermentation. It will be observed that leavening activity percentage ranges from 82 to $94.7 \%$ when compared with the commercial yeast that was used as control. Four (6) of the forty eight (12) isolates had leavening activity above $90 \%$ and the rest had activities between $80-90 \%$.

The low leavening activity of the negative control (dough which lacked yeast) confirms the effect of yeast on the fermented baked dough (Table 3).

Table 3 Leavening activity of isolates.

\begin{tabular}{|c|c|c|c|c|c|c|c|c|c|}
\hline \multirow{2}{*}{ Isolates } & \multicolumn{8}{|c|}{ Dough volumes $(\mathrm{ml})$ at intervals (mins)* } & \multirow{3}{*}{$\begin{array}{l}\text { Leavening \%** } \\
\text { N/A }\end{array}$} \\
\hline & 0 & 30 & 60 & 90 & 120 & 150 & 180 & 210 & \\
\hline Control & 29 & 29 & 29 & 29 & 29 & 29 & 29 & 29 & \\
\hline $\mathrm{CY}$ & 29 & 31 & 35 & 42 & 60 & 69 & 80 & 85 & 100 \\
\hline AY1 & 29 & 30.5 & 32 & 34 & 45 & 62 & 70 & 72 & 84.7 \\
\hline AY3 & 29 & 32 & 36 & 46 & 57 & 66 & 74 & 79 & 92.9 \\
\hline AY7 & 29 & 31 & 34 & 40 & 55 & 61 & 74 & 75 & 88.2 \\
\hline $\mathrm{AB} 2$ & 29 & 32 & 34 & 46 & 57.5 & 67 & 75 & 80.5 & 94.7 \\
\hline AB3 & 29 & 32 & 36 & 46 & 57 & 66 & 74 & 79 & 92.9 \\
\hline $\mathrm{AB} 7$ & 29 & 32 & 34 & 42 & 55 & 64 & 76 & 81.5 & 88.2 \\
\hline AJ2 & 29 & 32 & 36 & 42 & 55 & 71 & 78 & 80 & 94 \\
\hline AJ4 & 29 & 32 & 35 & 42 & 55 & 73 & 75 & 76 & 89.4 \\
\hline OK4 & 29 & 32 & 34 & 36 & 57 & 63 & 68 & 73 & 85.9 \\
\hline EG2 & 29 & 32 & 34 & 46 & 57.5 & 67 & 75 & 80.5 & 94.7 \\
\hline EG5 & 29 & 30 & 35 & 41.5 & 55 & 63 & 70.5 & 72 & 84.7 \\
\hline OC5 & 29 & 30 & 35 & 41.5 & 55 & 63 & 70.5 & 72 & 84.7 \\
\hline \multicolumn{10}{|l|}{$\begin{array}{l}\text { Commerci } \\
\text { AY1=Doug } \\
\text { AY3=Doug } \\
\text { AY7=Doug } \\
\text { AB2=Doug } \\
\text { AB3=Doug } \\
\text { AB7=Doug }\end{array}$} \\
\hline
\end{tabular}


AJ2=Dough prepared with yeasts from locations AJ2 AJ4=Dough prepared with yeasts from locations AJ4 OK4=Dough prepared with yeasts from locations OK4 $E G 2=$ Dough prepared with yeasts from locations $E G 2$ $E G 5=$ Dough prepared with yeasts from locations $E G 5$ $E G 8=$ Dough prepared with yeasts from locations $E G 8$ OC5=Dough prepared with yeasts from locations OC1

\section{The rate of $\mathrm{CO}_{2}$ production from different sugars}

The rate of $\mathrm{CO}_{2}$ production for the different sugars are shown in Tables 4-8. The rate of $\mathrm{CO}_{2}$ production was calculated as the gradient of $\mathrm{CO}_{2}$ released per minute. This ranges from $0.04-0.063 \mathrm{ml} / \mathrm{min}$ for glucose with $0.067 \mathrm{ml} / \mathrm{min}$ for commercial yeast, $0.028-0.061 \mathrm{ml} / \mathrm{min}$ for fructose with 0.061 $\mathrm{ml} / \mathrm{min}$ for commercial yeast, $0.044-0.067 \mathrm{ml} / \mathrm{min}$ for sucrose with $0.1 \mathrm{ml} / \mathrm{min}$ for commercial yeast, $0.028-0.061 \mathrm{ml} / \mathrm{min}$ for maltose with $0.078 \mathrm{ml} / \mathrm{min}$ for commercial yeast and $0.039-0.100 \mathrm{ml} / \mathrm{min}$ for mixed sugars with $0.164 \mathrm{ml} / \mathrm{min}$ for commercial yeast.

Table 4 Rate of $\mathrm{CO}_{2}$ production in $5 \%$ glucose.

\begin{tabular}{|c|c|c|c|c|c|c|c|}
\hline \multirow{2}{*}{ Isolates } & \multicolumn{6}{|c|}{$\mathrm{CO}_{2}$ released ( $\mathrm{ml} /$ minute) } & \multirow{3}{*}{$\begin{array}{l}\begin{array}{l}\text { Rate of } \mathrm{CO}_{2} \text { production }(\mathrm{ml} / \\
\mathrm{min})\end{array} \\
0.067\end{array}$} \\
\hline & 3 & 6 & 9 & 12 & 15 & 18 & \\
\hline $\mathrm{CY}$ & 0.45 & 0.7 & 0.85 & 1.05 & 1.25 & 1.45 & \\
\hline AY1 & 0.25 & 0.35 & 0.5 & 0.55 & 0.7 & 0.85 & 0.04 \\
\hline AY3 & 0.3 & 0.45 & 0.55 & 0.7 & 0.85 & 1.05 & 0.05 \\
\hline AY7 & 0.2 & 0.35 & 0.4 & 0.55 & 0.65 & 0.8 & 0.04 \\
\hline AB2 & 0.3 & 0.4 & 0.55 & 0.75 & 0.9 & 1.1 & 0.053 \\
\hline AB3 & 0.3 & 0.45 & 0.55 & 0.7 & 0.95 & 1.15 & 0.057 \\
\hline$A B 7$ & 0.15 & 0.35 & 0.45 & 0.5 & 0.7 & 0.8 & 0.043 \\
\hline AJ2 & 0.2 & 0.35 & 0.5 & 0.6 & 0.7 & 0.85 & 0.043 \\
\hline AJ4 & 0.25 & 0.45 & 0.55 & 0.75 & 0.9 & 1.2 & 0.063 \\
\hline OK4 & 0.2 & 0.4 & 0.5 & 0.7 & 0.85 & 1 & 0.053 \\
\hline EG2 & 0.15 & 0.35 & 0.5 & 0.55 & 0.7 & 0.8 & 0.043 \\
\hline EG5 & 0.2 & 0.35 & 0.5 & 0.6 & 0.75 & 0.95 & 0.05 \\
\hline OC5 & 0.2 & 0.35 & 0.5 & 0.65 & 0.7 & 0.85 & 0.043 \\
\hline \multicolumn{8}{|c|}{$\begin{array}{l}\text { All values are means of two readings. } \\
\text { Rate of } \mathrm{CO}_{2} \text { Production=slope of } \mathrm{CO}_{2} \text { released }(\mathrm{ml} \text { per min) } \\
\mathrm{CY}=\text { Suspension prepared with commercial yeast }\end{array}$} \\
\hline $\begin{array}{l}\text { AY1=Sus } \\
A Y 3=\text { Sus } \\
A Y 7=\text { Sus } \\
A B 2=\text { Sus } \\
A B 3=\text { Sus } \\
A B 7=\text { Sus } \\
\text { AJ2=Sus } \\
\text { AJ4=Sus } \\
\text { OK4=Sus } \\
E G 2=\text { Sus } \\
E G 5=\text { Sus } \\
\text { EG8=Sus } \\
\text { OC5=Sus }\end{array}$ & $\begin{array}{l}\text { red wi } \\
\text { ared wi } \\
\text { ared wi } \\
\text { ared wi } \\
\text { ared wi } \\
\text { ared wi } \\
\text { red wi } \\
\text { red wi } \\
\text { ared w } \\
\text { ared w } \\
\text { ared w } \\
\text { ared w } \\
\text { ared w }\end{array}$ & $\begin{array}{l}\text { n locat } \\
\text { n locat } \\
\text { n locat } \\
\text { n locat } \\
\text { n locat } \\
\text { n locat } \\
\text { n locat } \\
\text { n locat } \\
\text { m loca } \\
\text { m loca } \\
\text { m loca } \\
\text { m loca } \\
\text { m loca }\end{array}$ & & & & & \\
\hline
\end{tabular}

Table 5: Rate of $\mathrm{CO}_{2}$ production in $5 \%$ fructose.

\begin{tabular}{|c|c|c|c|c|c|c|c|}
\hline \multirow{2}{*}{ Isolates } & \multicolumn{6}{|c|}{$\mathrm{CO}_{2}$ released in $\mathrm{ml} / \mathrm{minute}$} & \multirow[t]{2}{*}{$\begin{array}{l}\text { Rate of } \mathrm{CO}_{2} \text { production }(\mathrm{ml} / \\
\text { min) }\end{array}$} \\
\hline & 3 & 6 & 9 & 12 & 15 & 18 & \\
\hline
\end{tabular}




\begin{tabular}{|c|c|c|c|c|c|c|c|}
\hline CY & 0.25 & 0.5 & 0.65 & 0.85 & 1.05 & 1.25 & 0.061 \\
\hline AY1 & 0.15 & 0.25 & 0.4 & 0.5 & 0.6 & 0.75 & 0.038 \\
\hline AY3 & 0.2 & 0.25 & 0.45 & 0.5 & 0.65 & 0.95 & 0.044 \\
\hline AY7 & 0.2 & 0.35 & 0.4 & 0.5 & 0.65 & 0.75 & 0.033 \\
\hline AB2 & 0.1 & 0.3 & 0.45 & 0.65 & 0.8 & 1.05 & 0.056 \\
\hline AB3 & 0.2 & 0.35 & 0.5 & 0.65 & 0.85 & 1.05 & 0.056 \\
\hline $\mathrm{AB} 7$ & 0.15 & 0.25 & 0.45 & 0.5 & 0.8 & 0.9 & 0.061 \\
\hline AJ2 & 0.2 & 0.35 & 0.5 & 0.65 & 0.7 & 0.95 & 0.039 \\
\hline AJ4 & 0.15 & 0.35 & 0.45 & 0.65 & 0.8 & 1.1 & 0.05 \\
\hline OK4 & 0.2 & 0.35 & 0.5 & 0.75 & 0.85 & 0.95 & 0.056 \\
\hline EG2 & 0.15 & 0.35 & 0.45 & 0.55 & 0.6 & 0.8 & 0.028 \\
\hline EG5 & 0.2 & 0.35 & 0.45 & 0.55 & 0.75 & 0.85 & 0.044 \\
\hline OC5 & 0.15 & 0.35 & 0.5 & 0.65 & 0.75 & 0.95 & 0.044 \\
\hline \multicolumn{8}{|c|}{$\begin{array}{l}\text { All values are means of two readings. } \\
\text { Rate of } \mathrm{CO}_{2} \text { Production=slope of } \mathrm{CO}_{2} \text { released }(\mathrm{ml} \text { per min) } \\
\mathrm{CY}=\text { Suspension prepared with commercial yeast }\end{array}$} \\
\hline $\begin{array}{l}\text { AY1= } \\
\text { AY3 }= \\
\text { AY7 }= \\
A B 2= \\
A B 3= \\
\text { AB7 }= \\
\text { AJ2= } \\
\text { AJ4= } \\
\text { OK4= } \\
\text { EG2= } \\
\text { EG5= } \\
\text { EG8= } \\
\text { OC5 }=\end{array}$ & $\begin{array}{l}\text { ared wit } \\
\text { ared wit } \\
\text { ared wit } \\
\text { ared wit } \\
\text { ared wit } \\
\text { ared wit } \\
\text { rred with } \\
\text { ired with } \\
\text { ared wit } \\
\text { ared wit } \\
\text { ared wit } \\
\text { ared wit } \\
\text { ared wi }\end{array}$ & $\begin{array}{l}\mathrm{m} \text { locat } \\
\mathrm{m} \text { locat } \\
\mathrm{m} \text { locat } \\
\mathrm{m} \text { locat } \\
\mathrm{m} \text { locat } \\
\mathrm{m} \text { locat } \\
\mathrm{m} \text { locat } \\
\mathrm{m} \text { locat } \\
\text { m loca } \\
\text { m loca } \\
\text { m loca } \\
\text { m loca }\end{array}$ & & & & & \\
\hline
\end{tabular}

Table 6 Rate of $\mathrm{CO}_{2}$ production $5 \%$ sucrose.

\begin{tabular}{|c|c|c|c|c|c|c|c|}
\hline \multirow{2}{*}{ Isolates } & \multicolumn{6}{|c|}{$\mathrm{CO}_{2}$ released in $\mathrm{ml} /$ minute } & \multirow{3}{*}{$\begin{array}{l}\begin{array}{l}\text { Rate of } \mathrm{CO}_{2} \text { production }(\mathrm{ml} / \\
\mathrm{min})\end{array} \\
0.1\end{array}$} \\
\hline & 3 & 6 & 9 & 12 & 15 & 18 & \\
\hline $\mathrm{CY}$ & 0.3 & 0.5 & 0.95 & 1.15 & 1.4 & 1.65 & \\
\hline AY1 & 0.25 & 0.45 & 0.65 & 0.85 & 0.9 & 1.15 & 0.05 \\
\hline AY3 & 0.2 & 0.35 & 0.65 & 0.75 & 0.95 & 1.25 & 0.067 \\
\hline AY7 & 0.2 & 0.35 & 0.45 & 0.65 & 0.85 & 1.15 & 0.056 \\
\hline AB2 & 0.2 & 0.4 & 0.65 & 0.85 & 1.15 & 1.35 & 0.044 \\
\hline AB3 & 0.25 & 0.45 & 0.65 & 0.75 & 0.9 & 1.05 & 0.05 \\
\hline$A B 7$ & 0.15 & 0.35 & 0.55 & 0.75 & 0.75 & 0.85 & 0.044 \\
\hline AJ2 & 0.2 & 0.35 & 0.5 & 0.7 & 0.75 & 0.95 & 0.056 \\
\hline AJ4 & 0.25 & 0.45 & 0.65 & 0.75 & 0.95 & 1.15 & 0.056 \\
\hline OK4 & 0.15 & 0.35 & 0.55 & 0.75 & 0.85 & 1.05 & 0.056 \\
\hline EG2 & 0.2 & 0.35 & 0.5 & 0.65 & 0.8 & 0.9 & 0.05 \\
\hline EG5 & 0.2 & 0.35 & 0.55 & 0.65 & 0.95 & 1.15 & 0.067 \\
\hline OC5 & 0.25 & 0.35 & 0.5 & 0.65 & 0.75 & 0.95 & 0.044 \\
\hline
\end{tabular}


All values are means of two readings.

Rate of $\mathrm{CO}_{2}$ Production=slope of $\mathrm{CO}_{2}$ released ( $\mathrm{ml}$ per min)

$\mathrm{CY}=$ Suspension prepared with commercial yeast

AY1=Suspension prepared with yeasts from locations AY1 AY3=Suspension prepared with yeasts from locations AY3 AY7 $=$ Suspension prepared with yeasts from locations AY7 $A B 2=S$ uspension prepared with yeasts from locations $A B 2$ $A B 3=$ Suspension prepared with yeasts from locations $A B 3$ $A B 7=$ Suspension prepared with yeasts from locations $A B 7$ AJ2=Suspension prepared with yeasts from locations AJ2 AJ4=Suspension prepared with yeasts from locations AJ4 OK4=Suspension prepared with yeasts from locations OK4 $E G 2=S u s p e n s i o n$ prepared with yeasts from locations $E G 2$ EG5=Suspension prepared with yeasts from locations EG5 $E G 8=S u s p e n s i o n$ prepared with yeasts from locations $E G 8$ OC5=Suspension prepared with yeasts from locations OC1

Table 7 Rate of $\mathrm{CO}_{2}$ production $5 \%$ maltose.

\begin{tabular}{|c|c|c|c|c|c|c|c|}
\hline \multirow{2}{*}{ Isolates } & \multicolumn{6}{|c|}{$\mathrm{CO}_{2}$ released in $\mathrm{ml} / \mathrm{minute}$} & \multirow{3}{*}{$\begin{array}{l}\begin{array}{l}\text { Rate of } \mathrm{CO}_{2} \text { production }(\mathrm{ml} / \\
\mathrm{min})\end{array} \\
0.078\end{array}$} \\
\hline & 3 & 6 & 9 & 12 & 15 & 18 & \\
\hline CY & 0.2 & 0.3 & 0.65 & 0.85 & 1 & 1.25 & \\
\hline AY1 & 0.15 & 0.35 & 0.45 & 0.55 & 0.6 & 0.7 & 0.028 \\
\hline AY3 & 0.2 & 0.35 & 0.45 & 0.65 & 0.65 & 0.75 & 0.033 \\
\hline AY7 & 0.2 & 0.35 & 0.4 & 0.55 & 0.65 & 0.75 & 0.033 \\
\hline AB2 & 0.2 & 0.3 & 0.5 & 0.75 & 0.85 & 0.9 & 0.061 \\
\hline AB3 & 0.15 & 0.2 & 0.3 & 0.45 & 0.6 & 0.75 & 0.044 \\
\hline $\mathrm{AB} 7$ & 0.25 & 0.45 & 0.55 & 0.65 & 0.85 & 0.95 & 0.044 \\
\hline AJ2 & 0.2 & 0.35 & 0.55 & 0.75 & 0.85 & 1.05 & 0.057 \\
\hline AJ4 & 0.25 & 0.4 & 0.65 & 0.85 & 0.95 & 1.15 & 0.061 \\
\hline OK4 & 0.15 & 0.35 & 0.5 & 0.65 & 0.75 & 0.95 & 0.044 \\
\hline EG2 & 0.15 & 0.35 & 0.5 & 0.65 & 0.8 & 0.95 & 0.05 \\
\hline EG5 & 0.2 & 0.3 & 0.5 & 0.6 & 0.75 & 0.85 & 0.05 \\
\hline OC5 & 0.2 & 0.3 & 0.5 & 0.65 & 0.75 & 0.85 & 0.05 \\
\hline
\end{tabular}

All values are means of two readings.

Rate of $\mathrm{CO}_{2}$ Production=slope of $\mathrm{CO}_{2}$ released $(\mathrm{ml}$ per $\mathrm{min}$ )

$\mathrm{CY}=$ Suspension prepared with commercial yeast

AY1=Suspension prepared with yeasts from locations AY1 AY3=Suspension prepared with yeasts from locations AY 3 $A Y 7=$ Suspension prepared with yeasts from locations $A Y 7$ $A B 2=S u s p e n s i o n$ prepared with yeasts from locations $A B 2$ $A B 3=$ Suspension prepared with yeasts from locations $A B 3$ $A B 7=$ Suspension prepared with yeasts from locations $A B 7$ $\mathrm{AJ} 2=$ Suspension prepared with yeasts from locations $\mathrm{AJ} 2$ AJ4=Suspension prepared with yeasts from locations AJ4 OK4=Suspension prepared with yeasts from locations OK4 $E G 2=$ Suspension prepared with yeasts from locations EG2 $E G 5=S u s p e n s i o n$ prepared with yeasts from locations EG5 $E G 8=$ Suspension prepared with yeasts from locations EG8 $\mathrm{OC} 5=$ Suspension prepared with yeasts from locations $\mathrm{OC} 1$

Table 8 Rate of $\mathrm{CO}_{2}$ production from mixed sugars.

\begin{tabular}{|l|l|l|l|l|l|l|}
\hline \multirow{2}{*}{ Isolates } & \multicolumn{4}{|l|}{$\mathrm{CO}_{2}$ released in ml/minute } & \multicolumn{2}{|c|}{ Rate of CO ${ }_{2}$ production(ml/min) } \\
\cline { 2 - 7 } & $\mathbf{3}$ & $\mathbf{6}$ & $\mathbf{9}$ & $\mathbf{1 2}$ & $\mathbf{1 5}$ & $\mathbf{1 8}$ \\
\hline $\mathrm{CY}$ & 0.45 & 0.7 & 0.95 & 1.25 & 1.55 & 1.8 \\
\end{tabular}




\begin{tabular}{|c|c|c|c|c|c|c|c|}
\hline AY1 & 0.3 & 0.45 & 0.65 & 0.85 & 1.05 & 1.35 & 0.067 \\
\hline AY3 & 0.3 & 0.55 & 0.75 & 0.9 & 1.25 & 1.45 & 0.078 \\
\hline AY7 & 0.35 & 0.5 & 0.75 & 0.95 & 1.15 & 1.45 & 0.072 \\
\hline $\mathrm{AB} 2$ & 0.3 & 0.6 & 0.75 & 0.95 & 1.15 & 1.45 & 0.061 \\
\hline AB3 & 0.25 & 0.45 & 0.65 & 0.9 & 1 & 1.25 & 0.061 \\
\hline $\mathrm{AB} 7$ & 0.25 & 0.55 & 0.75 & 0.95 & 1.15 & 1.4 & 0.067 \\
\hline AJ2 & 0.25 & 0.45 & 0.55 & 0.75 & 0.9 & 1.05 & 0.05 \\
\hline AJ4 & 0.25 & 0.55 & 0.85 & 1.05 & 1.45 & 1.7 & 0.1 \\
\hline OK4 & 0.3 & 0.45 & 0.75 & 1 & 1.05 & 1.3 & 0.067 \\
\hline EG2 & 0.35 & 0.55 & 0.65 & 0.85 & 0.9 & 1.1 & 0.039 \\
\hline EG5 & 0.2 & 0.35 & 0.55 & 0.7 & 0.95 & 1.2 & 0.067 \\
\hline OC5 & 0.25 & 0.45 & 0.65 & 0.85 & 1 & 1.15 & 0.061 \\
\hline \multicolumn{8}{|c|}{$\begin{array}{l}\text { All values are means of two readings. } \\
\text { Rate of } \mathrm{CO}_{2} \text { Production=slope of } \mathrm{CO}_{2} \text { released }(\mathrm{ml} \text { per min) } \\
\mathrm{CY}=\text { Suspension prepared with commercial yeast }\end{array}$} \\
\hline \multicolumn{8}{|c|}{$\begin{array}{l}\text { AY1=Suspension prepared with yeasts from locations } A Y 1 \\
\text { AY3=Suspension prepared with yeasts from locations AY3 } \\
\text { AY7=Suspension prepared with yeasts from locations AY7 } \\
\text { AB2=Suspension prepared with yeasts from locations AB2 } \\
\text { AB3=Suspension prepared with yeasts from locations AB3 } \\
\text { AB7 }=\text { Suspension prepared with yeasts from locations AB7 } \\
\text { AJ2=Suspension prepared with yeasts from locations AJ2 } \\
\text { AJ4=Suspension prepared with yeasts from locations AJ4 } \\
\text { OK4=Suspension prepared with yeasts from locations OK4 } \\
\text { EG2=Suspension prepared with yeasts from locations EG2 } \\
\text { EG5=Suspension prepared with yeasts from locations EG5 } \\
\text { EG8=Suspension prepared with yeasts from locations EG8 } \\
\text { OC5=Suspension prepared with yeasts from locations OC1 }\end{array}$} \\
\hline
\end{tabular}

Table 9 Stress exclusion tests result.






\section{Stress exclusion tests results}

There was intensive response of growth with temperature $30^{\circ} \mathrm{C}$, while at $37^{\circ} \mathrm{C}$ moderate to intensive responses were observed. Temperature $45^{\circ} \mathrm{C}$ witnessed a no response to scanty or low response to growth.

The ethanol tolerance was generally intensive at $8 \%$ concentration, moderate to slight at $10 \%$ and generally low or nil at $13 \%$ to growth of the isolate. The isolates were able to tolerate 6 and $8 \% \mathrm{w} / \mathrm{v}$ salt but very few tolerated $10 \%$.

\section{Discussion}

Palm wine is an abundant product in Nigeria. Anyigba and its environs are abundantly blessed with palm wine. The leavening activities of various yeasts isolated from palm wine in this study shows that the wine is a rich source of potential bakery yeasts. Interestingly, they occurred in palm wine from all the locations from which samples were taken.

All the yeast strains including the commercial strain did not ferment lactose and xylose. Tarek [33] reported the S. cerevisiae cells which were unable to ferment lactose were actually due to lack of lactase or $\beta$-galactosidase system. It was also shown that all yeast strains which utilized respective sugars also produced carbon dioxide (Table 2). The carbon dioxide released during dough fermentation process is prominent as a leavening agent of dough [34].

The assimilation of sugars varied among the isolates which indicated some metabolic diversity of palm wine yeasts that can be harnessed in industrial applications.

In primary role of baker's yeast in dough development, fermentative capacity using carbon source simultaneously with the production of carbon dioxide is an important parameter for bread making [35]. It is interesting that all yeast strains tested that were identified as $S$. cerevisiae were able to assimilate many of the sugars tested.

Palm wine contains a high level of sucrose (10\%). This sugar level favors the growth of yeasts. It further gives credence to the general belief held in the early days of research that yeasts are found in sugary substances [36].

Yeast, specifically Saccharomyces cerevisiae, is used in baking as a leavening agent, where it converts the fermentable sugars present in the dough into carbon dioxide. This causes the dough to expand or rise as the carbon dioxide forms pockets or bubbles. When the dough is baked, the pockets remain, giving the baked product a soft and spongy texture. The data on leavening activity showed that the isolated yeasts increased the size of the dough which they fermented considerably are in agreement with the results of Okagbue [37]. The result is supported by the abilities of the yeasts to ferment sugars especially glucose and fructose, the breakdown of which brings about the release of carbon dioxide that caused the dough to rise.

The highest leavening activity recorded for $S$. cerevisiae indicates that it is the best biological wheat dough leavener obtained in this work because it can perform better than the commercial yeasts used as controls. The result is in agreement with the findings of Somairi and Udoh [38] and Adenaike et al. [39] who reported that Saccharomyces species isolated from palm wine were found to be the best in leavening wheat dough.

The low leavening activity of the negative control (dough which lacked yeast) confirms the effect of yeast on the fermented baked dough. Yeast cells produce ethanol and $\mathrm{CO}_{2}$ as byproducts, and the ethanol produced becomes a valuable energy source. Ethanol and $\mathrm{CO}_{2}$ are produced by yeasts during fermentation (the $\mathrm{CO}_{2}$ is what leavens bread and gives beer its fizz). Carbon dioxide production can be measured quickly and accurately, and it affords an acceptable means of studying the effects of different variables on yeast fermentation. It is interesting that the release of quantifiable $\mathrm{CO}_{2}$ by the strains corresponded roughly with the leavening potential as shown with selected strains for $\mathrm{CO}_{2}$ production. Thus, the strains with high levels of $\mathrm{CO}_{2}$ production can be used in other processes where gas can be trapped for commercial purposes.

In bread manufacture, there are different sources of fermentable sugars. One, the sugar present in the dough at the start of the bread-making process (including the glucose, fructose, sucrose and maltose naturally present in the flour) and two, any other fermentable sugar such as sucrose added by the baker. The amount of fermentable sugar added by the baker varies, but can reach $25 \% \mathrm{w} / \mathrm{w}$ in some. In this sweet dough, the ability of the yeast to ferment under conditions of high osmotic stress is of crucial industrial importance. Also, maltose is produced by the amylolytic breakdown of starch. In bread made without added sugars (plain dough), the pre-existing free sugars are completely fermented within the first hour, leaving only the starch-derived maltose to sustain fermentation. In plain dough, the ability of the yeast to rapidly ferment maltose is thus of crucial industrial importance [40].

The Saccharomyces species in the samples under test had high ethanol tolerance [13\% (v/v)] and were not inhibited by that level of ethanol (Table 9). Ethanol tolerance is a unique property of the yeast that makes it exploitable for industrial applications.

In stress exclusion test, yeast colonies were examined in order to select the strains which were able to adapt in bread making conditions. Using strains which were not effectively adapted to stress conditions could lead to stuck fermentation [41].

Survival of baker's yeast under various stress conditions could provide useful information on its ability to grow and carry out fermentation as impaired yeast. The growth of impaired yeast during fermentation may not be optimal especially when it is exposed to several stresses such as osmotic and ethanol stress [42]. In this work, as indicated in appendix B, some of the yeast strains were able to grow under stressful conditions. It is reported by Pataro et al. [43] who reported that most of $S$. cerevisiae strains isolated from conventional fermentation processes were physiologically adapted to extreme conditions. In that study the strains were able to grow on medium (yeast potato broth) containing $20 \%(\mathrm{w} / \mathrm{v})$ glucose and $8 \%(\mathrm{v} / \mathrm{v})$ ethanol and incubated at $37^{\circ} \mathrm{C}$. 
Since the yeast cells in bread making produce ethanol as secondary metabolite the ethanol stress tests were conducted to observe its tolerance to ethanol. A suitable concentration of alcohol is needed in bread making in order to achieve the preferred flavor. As shown in Table 9, all yeast strains were able to grow in a medium containing $10 \%(\mathrm{v} / \mathrm{v})$ of ethanol. At $13 \%$ $(\mathrm{v} / \mathrm{v})$ of ethanol concentration, all yeast strains were able to grow in the respective broth medium. High concentration of alcohol is reported to be toxic to the yeast by inhibiting the cells growth due to the destruction of the cell membrane [44-46]. In this experiment, the highest concentration of ethanol in which the commercial yeast strain was able to survive was at $13 \%$ $(v / v)$. Those strains which were capable of growing in similar concentration were expected to have ability to produce similar quality of bread as commercial strain.

The selected yeast strains were also tested for their growth at high temperature (Table 9). Most of the yeast strains could tolerate temperatures up to $37^{\circ} \mathrm{C}$. Therefore it can be said that most yeasts isolated from different locations in Anyigba and its environs were able to grow at high ethanol concentration (13\%) and at high temperature $\left(37^{\circ} \mathrm{C}\right)$.

All the yeast strains show high tolerance to varying concentrations of salt $(8 \%, 10 \%$, and $13 \%)$. The significance of salt tolerance lies in the fact that in Nigeria, experience shows that some bakeries use salt instead of sugar because the former is cheaper and preferred by people with some health condition such as diabetes. Salt has several functions in baked goods. It modifies flavour, increases crust color and controls the rate of yeast fermentation and enzyme activity. Salt also strengthens gluten, making it more cohesive and less sticky. With salt present, gluten holds more water and carbon dioxide, allowing the dough to expand without tearing [47].

The flocculation abilities were also tested on the yeasts strains. According to Amri et al. [48] and Miki et al. [49], yeast cells which had ability to flocculate caused by cell adhesion process is an interesting process. The flocculation characteristic was determined by yeast cells sticking together and provides easy separation from the broth medium. This phenomenon has an economic effect on the production of yeast biomass due to the fact that it can reduce the energy cost involved in biomass centrifugation [50,51]. In addition, flocculation properties of $S$. cerevisiae ensure a high cell density and large volume of harvested cells and also able to raise the ethanol productivity during the fermentation process [52-54]. Initiation of flocculation ability of Saccharomyces cerevisiae cells was observed at the moment the cells stop dividing because of nitrogen limitation. A shift in concentration of the limiting nutrient resulted in a corresponding shift in cell division and initiation of flocculence [55].

\section{Conclusion}

This work evaluated the properties of palm wine yeasts for possible bakery application. Palm wine has proved to be a reliable source from which to isolate strains of $S$. cerevisiae that have well defined industrial properties. The yeast cells had high viability, high leavening capacity, $\mathrm{CO}_{2}$ production, temperature tolerance, ethanol tolerance and osmotic tolerance.

\section{Contribution to Knowledge}

From the work carried out, it can be seen that Saccharomyces cerevisiae strain isolated from all the locations possess properties such as leavening activity, high rate of $\mathrm{CO}_{2}$ production; hence, the are potentially useful as raw materials for bakery industry. This implies there can be a reduction of cost and time for yeast importation for bakeries.

\section{Recommendation}

Further work will be needed to assess the ability of the isolates from this work to produce palatable bread comparable with that of commercial yeasts.

Also, process optimization in terms of studies on nutritional (e.g. vitamin) requirements of the yeasts would be necessary before they can be propagated on a large scale.

\section{Acknowledgments}

My heartfelt gratitude goes to my supervisor, Professor Richard. Nnamdi Okagbue, for his love, care, help, patience and kind gesture in putting me through all the rudiments of the research work. In fact I have learnt and acquired more experience in his supervision.

And to member of Staff of the Laboratory of the Department of Microbiology, Kogi State University, Anyigba, Nigeria.

\section{References}

1. Adenaike O, Ameh JB, Whong CMZ (2006) Comparative studies of the fermentative capacity of baker's yeast and local yeast strains (Saccharomyces species) isolated from fermented beverages. Annual Conference of Nigerian Society of Microbiology.

2. Amendola J, Rees N (2002) Understanding Baking: The Art and Science of Baking. John Wiley and Sons.

3. Amri MA, Bonaly R, Duteutre B, Moll M (1982) Yeast Flocculation: Influence of nutritional factors on cell wall composition. J Gen Microbiol 128: 2001-2009.

4. Ayanru KG (1989) Morphological and physiological variants among isolates of Saccharomyces cerevisiae from palm wine and other sources. J Sci Food Agr 49: 193-202.

5. Ayemor GKS, Matthew JS (1972) The sap of the palm Elaeis guineensis, a raw material for alcoholic fermentation in Ghana. Tropical Science 13: 71-83.

6. Ayogu TE (1999) Evaluation of the performance of yeast isolate (Saccharomyces cerevisiae) from Nigeria palm wine in production from pineapple mist. Bioresour Technol 69: 189-190.

7. Barneth J, Payne R, Yarrow D (1990) Yeast: Characteristics and Identification. 2nd Edition Cambridge Univ Press.

8. Bassir O (1982) Observation of the fermentation of palm-wine. West African Journal Biology Applied Chemistry 10: 42-45.

9. Bell PJL, Higgins VJ, Attfield PV (2001) Comparison of fermentative capacities of industrial baking and wild-type yeasts of the species 
Saccharomyces cerevisiae in different sugar media. J Appl Microbiol 32: 224-229.

10. Bhate DS (1955) Pumilin, a new antibiotic from Bacillus pumilus. Nature 175: 816-817.

11. Benitez B, Gasent RJM, Castrejon F, Codon AC (1996) Development of new strains for the food industry. Biotechnol Prog 12: 149-163.

12. Browning KC, Symons CTS (1961) Coconut Toddy in Ceylon. Journal of Society and Chemistry Industry 35: 10238-11142.

13. Charley H (1986) Food Science. 2nd edition New York: Macmillan Publishing Company.

14. Cogliati M (2013) Global molecular epidemiology of Cryptococcus neoformans and Cryptococcus galtii: An Atlas of the molecular types. Scientifica.

15. Essiamah SK (1989) Second Pacific Regional Wood Anatomy Conference. PRWAC 10: 335.

16. Ezeronye OU, Okerentugba PO (2001) Genetic and physiological variants of yeast selected from palm wine. Mycopathologia 152: 85-89.

17. Fawole R, Oso O (1998) Laboratory manual of microbiology. 2nd edition Spectrum Books Limited, Ibadan, Nigeria.

18. Faparusi SI (1969) Effect of $\mathrm{pH}$ on the Preservation of Palm Wine by Sulfite. Appl Microbiol 18: 122-123.

19. Fardi H, Faubion JM (1990) Dough theology and baked product texture. Van Nostrand Reinhold Publisher, New York.

20. Frazier WC, Westhoff DC (1995) Food Microbiology 4th Ed. New Delhi: Tata McGraw-Hill Publishing Company limited.

21. Ihekoronye AJ, Ngoddy PO (1985) Integrated food science and technology for the tropic. Fifth Edition. Macmillan Publishers, London, New York.

22. Ingram LO, Buttke TM (1984) Effects of alcohols on microorganisms. Adv Microb Physiol 25: 253-300.

23. Iraj N, Giti E, Lila A (2002) Isolation of a flocculation of Saccharomyces cerevisiae and investigation of its performance in the fermentation of beet molasses to ethanol. American Journal of Biomass and Bioenergy 23: 481-486.

24. Irele PT, Koleso OA (1977) A literature review on palm wine. Federal Institute of Industrial Research and Technology.

25. Ivorra C, Perez OJE, Olmo M (1999) An inverse correlation between stress resistance and stuck fermentations in wine yeasts. Biotechnol Bioeng 64: 698-708.

26. Jay JM (1986) Modern food microbiology. 3rd Edition C.B.S publishers and distributors.

27. Kevin K (2005) Fungi: Biology and Applications. England: John Wiley and Sons, Ltd.

28. Leao CV, Uden N (1984) Effects of ethanol and other alkanols on passive proton influx in the yeast Saccharomyces cerevisiae. Biochim Biophys Acta 774: 43-48.

29. Maravilla JN (1974) Toddy tapping: its effect on the yield of coconut. Philippine Coconut Authority.

30. Martini A (1992) Biodiversity and conservation of yeasts. Biodivers Conserv 4: 324-333.

31. Miki BL, Poon NH, Seligy VL (1982) Repression and induction of flocculation interactions in Saccharomyces cerevisiae. J Bacteriol 150: 890-899.
32. Nwokeke NV (2001) Palm wine Preservation using Traditional plants that have preservative bases. B.Sc. Thesis. Imo State University, Owerri, Nigeria.

33. Nwachukwu IN, Ibekwe VI, Nwabueze RN, Anyanwu BN (2006) Characterisation of palm wine yeast isolates for industrial utilization. Afr J Biotechnol 5: 1725-1728.

34. Ogbulie TE, Ogbulie JN, Njoku HO (2007) Comparative study on the shelf life stability of palm wine from Elaeis guineensis and Raphia hookeri: obtained from Okigwe, Nigeria. Afr J Biotechnol 6: 914-922.

35. Okafor N (1972) Palm Wine Yeasts from parts of Nigeria. J Sc fd Agric 23: 1399-1407.

36. Okafor $N$ (1978) Preliminary studies on preservation of palm wine. J Appl Bacteriol 38: 1-7.

37. Okafor N (1987) Industrial Microbiology. University of Ile Ife Press Ltd.

38. Okagbue RN (1988) A note on the leavening activity of yeasts isolated from Nigerian palm wine. J Appl Bacteriol 64: 235-240.

39. Oyawoye OM, Oyawoye EO, Bassey BK (1993) Dough raising fermentation ability of local yeast isolated from molasses. Nigerian Food Journal 1: 48-53.

40. No authors (2013) Citing Websites in Palmwine. Wikipedia.

41. Pataro C, Guerra JB, Petrillo-Peixoto ML, Mendonça HLC, Linard VR, et al. (2000) Yeast communities and genetic polymorphism of Saccharomyces cerevisiae strains associated with artisanal fermentation in Brazil. J Appl Microbiol 88: 1-9.

42. Phaff HJ, Starmer WT (1987) The Yeasts, A Taxonomic Study. 3rd Edition. Elsevier, Amsterdam.

43. Querol A, Fernández-Espinar MT, del Olmo MI, Barrio E (2003) Adaptive evolution of wine yeast. Int J Food Microbiol 86: 3-10.

44. No authors (2014) Citing Websites in Saccharomyces cerevisiae. Wikipedia.

45. Sherman FH (1986) Methods in yeast genetics. Cold Spring Harbor Laboratory Press, NY.

46. Smit G, Straver MH, Lugtenberg BJ, Kijne JW (1992) Flocculence of Saccharomyces cerevisiae cells are induced by nutrient limitation, with cell surface hydrophobicity as a major determinant. Appl Environ Microbiol 58: 3709-3714.

47. Snodgrass ME (2004) Encyclopedia of Kitchen History. Ney York.

48. Somiari RI, Udoh AE (1993) Evaluation of performance of yeast isolated from the sap of Elaeis guineensis in dough leaving. Nigerian food journal 2: 34-43.

49. Spencer JFT, de Spencer LAR (2001) Methods in molecular biology. Food microbiology protocols 14: 232-236.

50. Spilatro RS (2014) In Yeast on the Rise. Marietta College.

51. Sultan WJ (1982) Practical baking. 3rd Edition, Avi Publishing Company West Port, Connecticut.

52. Tarek MEN (2001) Immobilization of recombinant strains of Saccharomyces cerevisiae for the hydrolysis of lactose in salted Domiati cheese whey. Eur Food Res Technol 212: 225-227.

53. Thais M, Guimarães DG, Moriel IP, Machado B, Cyntia MT, et al. (2006) Isolation and characterization of Saccharomyces cerevisiae strains of winery interest. Braz J Pharm Sci 42: 119-126. 
54. Timerman AP, Fenrick AM, Zamis TM (2009) The Isolation of Invertase from Baker's Yeast, A Four Part Exercise in Protein Purification and Characterization. J Chem Educ 86: 379-381.

55. Vicent JH, Mark B, Phill B, Peter B, Ian WD, et al. (1999) Genetic evidence of maltase and invertase activity on high efficient gas producing yeast cells in unsugared dough. Applied Environ Microbial 65: 680. 